\title{
Airborne radionuclides and heavy metals in high Arctic terrestrial environment as the indicators of sources and transfers of contamination
}

\author{
Edyta Lokas $^{1}$, Agata Zaborska $^{2}$, Ireneusz Sobota ${ }^{3}$, Paweł Gaca ${ }^{4}$, J. Andrew Milton ${ }^{4}$, Pawel Kocurek ${ }^{5}$, and \\ Anna Cwanek ${ }^{1}$ \\ ${ }^{1}$ Department of Nuclear Physical Chemistry, Institute of Nuclear Physics, Polish Academy \\ of Sciences, Kraków, 31-342, Poland \\ ${ }^{2}$ Marine Chemistry and Biochemistry Department, Institute of Oceanology, Polish Academy \\ of Sciences, Sopot, 81-712, Poland \\ ${ }^{3}$ Department of Hydrology and Water Management, Polar Research Centre, Nicholas Copernicus \\ University, Toruń, 87-100, Poland \\ ${ }^{4}$ School of Ocean and Earth Science, University of Southampton, National Oceanography Centre, \\ European Way, Southampton, SO14 3ZH, UK \\ ${ }^{5}$ Research and Development Laboratory for Aerospace Materials, Rzeszów University of Technology, \\ Rzeszów, 35-959, Poland
}

Correspondence: Edyta Łokas (edyta.lokas@ifj.edu.pl)

Received: 18 February 2019 - Discussion started: 15 March 2019

Revised: 20 June 2019 - Accepted: 29 June 2019 - Published: 29 July 2019

\begin{abstract}
A survey of airborne radioactive isotopes $\left({ }^{137} \mathrm{Cs}\right.$, ${ }^{238} \mathrm{Pu},{ }^{239+240} \mathrm{Pu},{ }^{241} \mathrm{Am}$, and $\left.{ }^{210} \mathrm{~Pb}\right)$ and trace metals $(\mathrm{Pb}$, $\mathrm{Cu}, \mathrm{Zn}, \mathrm{Cd}, \mathrm{Fe}, \mathrm{Al}$ ) in tundra soils and cryoconite hole material sampled from several locations in the Kaffiøyra region of Spitsbergen revealed significant variability in spatial concentration. Lithogenic radionuclides $\left({ }^{230} \mathrm{Th},{ }^{232} \mathrm{Th},{ }^{234} \mathrm{U},{ }^{238} \mathrm{U}\right)$ show less variability than the airborne radionuclides because their activity concentrations are controlled by mixing of local material derived from different types of bedrock.

Activity ratios of the artificial radionuclides in most cryoconite samples differ from global fallout signatures. The contribution of radionuclides from additional and more specific sources might be enhanced by non-continuous exposure of cryoconite to atmospheric deposition. We assumed that the main source of $\mathrm{Pu}$, which was detected only in cryoconite samples, is derived from nuclear tests and nonexploded weapons-grade material. Approximately one-third of the total observed $\mathrm{Pu}$ activity concentration is ${ }^{238} \mathrm{Pu}$, most likely originating from the SNAP9A satellite re-entry, which was powered by a ${ }^{238} \mathrm{Pu}$ thermoelectric generator. In samples from Waldemarbreen the influence of glacial local morphology on the capability of cryoconite for trapping and ac-
\end{abstract}

cumulating airborne radionuclides is apparent. Local glacial morphology plays an important role in determining the accumulation of airborne pollutants. Trace metal concentrations in soils were typical or slightly higher than concentrations characteristic for the natural background; the ${ }^{206} \mathrm{~Pb} /{ }^{207} \mathrm{~Pb}$ signature was also close to the natural ratio of the parent rocks. Conversely, trace metal concentrations in cryoconite samples $(\mathrm{Pb}$ and $\mathrm{Cd})$ were higher than in soil samples and exceeded natural values. Cryoconite is an effective monitor of the spread of artificial radionuclides and heavy metals in their surrounding environment.

\section{Introduction}

The radioactive nuclides in the environment originate from both natural and anthropogenic sources. The present work is focused on ${ }^{137} \mathrm{Cs},{ }^{238,239,240} \mathrm{Pu}$, and ${ }^{241} \mathrm{Am}$, which have been produced through nuclear fission and neutron activation processes and have been released to the environment mainly in the second half of the 20th century. The main sources of an- 
thropogenic radionuclides in the Northern Hemisphere are (i) nuclear weapon tests and atmospheric explosions (e.g. Novaya Zemlya, Semipalatinsk, Nevada), (ii) nuclear accidents (e.g. Kyshtym 1957, Lake Karachay 1968, Tomsk 1993, Chernobyl 1986, Fukushima 2011), and (iii) the disintegration of satellites powered by nuclear thermoelectric generators (e.g. SNAP9A-1964, Cosmos 958-1978). Relatively low but constant releases of artificial radioisotopes are also associated with the reprocessing of spent nuclear fuel and energy generation in nuclear power plants. Heavy metals are natural elements of the Earth's crust. Since the beginning of the industrial era (from $\sim 1850$ ) the deposition of metals in the environment due to human activities has increased nearly 10-fold (Nriagu, 1996). The emission of heavy metals increased substantially after World War II and is still increasing in some areas. The primary sources of anthropogenic heavy metals include industry, mining, agriculture, fuel burning, waste disposal, and transportation (Pacyna and Pacyna, 2001). Artificial radionuclides and heavy metals are transported across the world mainly via the atmosphere, oceanic currents, and rivers. These materials can be found in remote Earth locations like the polar cryosphere. Elevated radionuclide and heavy metal levels have been reported in Asian and European glaciers (Barbante et al., 2004; Aizen et al., 2009; Eyrikh et al., 2017; Baccollo et al., 2017) and in remote Arctic and Antarctic areas (Hur et al., 2007; Singh et al., 2013).

The most significant quantities of these pollutants on glaciers are most likely stored in cryoconite granules and microfauna (Segawa et al., 2013; Łokas et al., 2016; Baccolo et al., 2017; Zawierucha et al., 2018). Cryoconite granules are aggregates of mineral and organic components, mainly composed of archaea, algae, cyanobacteria, fungi, and heterotrophic bacteria (Cook et al., 2015; Simon and Bouville, 2002; Takeuchi et al., 2001a, b; Hodson et al., 2008). Cyanobacteria play a crucial role in the formation of these aggregates as they produce extracellular polymeric substances (EPSs) whose adhesive properties enhance the accumulation of mineral dust and microorganisms (Gadd, 2004; Francis, 2007). Cryoconite holes are formed on the ablation zone of glaciers and constitute nutrient-rich pools with diverse biota within the supraglacial zone (Wharton et al., 1985; Cook et al., 2016). Dark-coloured cryoconite significantly increases the absorption of solar light by glaciers, enhancing and accelerating melting processes (Simon and Bouville, 2002; Takeuchi et al., 2001a, b; Hodson et al., 2008). Glaciers in Canada, the Russian Arctic, Alaska, Antarctica, and Greenland are projected to lose about $40 \%$ of their volume by the end of 2100; central Europe, low-latitude South America, Caucasus, northern Asia, western Canada, and the US are expected to lose about $80 \%$ of their volume or entirely disappear within decades at current climatic conditions (Radic et al., 2014). Cryoconite granules contain high concentrations of contaminants and can persist on glacier surfaces for several decades (Łokas et al., 2014). As glacier ice disappears, their contents are deposited on freshly ex- posed areas. The discovery of hotspots of radioactivity in the proglacial zones of Spitsbergen glaciers (Łokas et al., 2014, 2017b) provided evidence that cryoconite-derived contaminants were dispersed by meltwater channels and accumulated in depressions of the glacier fore field. The monitoring and fate of anthropogenic radionuclides and heavy metal distribution are important as both pose a potential threat to the environment. During intense cryosphere melting, contaminants accumulated over many decades on glacier surfaces are released and can pollute local vegetation, surface waters, and even drinking water sources (Dong et al., 2017). Additionally, the determination of Pu isotopes, ${ }^{241} \mathrm{Am}$, and ${ }^{137} \mathrm{Cs}$ in cryoconite has great potential for monitoring the environmental impact of military nuclear activities, the rising number of nuclear events in civilian nuclear installations, and the growing risk of nuclear terrorism and undeclared nuclear activities.

The main objective of this study is to evaluate the concentrations of artificial $\left({ }^{137} \mathrm{Cs},{ }^{238,239+240} \mathrm{Pu},{ }^{241} \mathrm{Am}\right)$ and natural $\left({ }^{210} \mathrm{~Pb},{ }^{230} \mathrm{Th},{ }^{232} \mathrm{Th},{ }^{234} \mathrm{U},{ }^{238} \mathrm{U}\right)$ radionuclides and trace metals $(\mathrm{Pb}, \mathrm{Cu}, \mathrm{Zn}, \mathrm{Cd}, \mathrm{Fe}, \mathrm{Al})$ in cryoconite holes and tundra soils sampled in several locations in the Kaffiøyra region (Spitsbergen) and to identify and constrain the different sources of contamination based on the isotopic ratios of measured radionuclides and metals $\left({ }^{238} \mathrm{Pu} /{ }^{239+240} \mathrm{Pu},{ }^{241} \mathrm{Am} /{ }^{239+240} \mathrm{Pu},{ }^{239+240} \mathrm{Pu} /{ }^{137} \mathrm{Cs}\right.$, ${ }^{240} \mathrm{Pu} /{ }^{239} \mathrm{Pu},{ }^{206} \mathrm{~Pb} /{ }^{207} \mathrm{~Pb}$, and ${ }^{208} \mathrm{~Pb} /{ }^{206} \mathrm{~Pb}$ ).

\section{Data and methods}

\subsection{Study area}

The Kaffiøyra region (Fig. 1), located in northwestern Spitsbergen, the adjoining Aavatsmarkbreen $\left(75 \mathrm{~km}^{2}\right)$, and the Dahlbreen $\left(132 \mathrm{~km}^{2}\right)$ together comprise an area of about $310 \mathrm{~km}^{2}$ (Sobota et al., 2016). It is a coastal lowland at Forlandsundet (Forland Sound) and accounts for $12 \%$ of the area of Oscar II Land. Along with Kaffiøyra, which is $14 \mathrm{~km}$ long and $4 \mathrm{~km}$ wide, seven land glaciers are located in this region. The main pedogenetic processes in the Kaffiøyra region consist of the accumulation of organic material, gleying, and decarbonation. Cryogenic processes, which overlap the pedogenetic processes, also play an important role in the genesis of the soils. The substantial moisture content of the surface layers and stagnant waters result in a shallow permafrost (Plichta, 2005). During 1996-2015, the greatest average thickness of active permafrost $(215 \mathrm{~cm})$ was recorded at a location in the moraine. A much lower mean value was recorded on the beach $(126 \mathrm{~cm})$. An active layer in the tundra reached on average a depth of $150 \mathrm{~cm}$ (Sobota et al., 2018). Climate research in the Kaffiøyra region has been conducted since 1975. The increase in air temperature noted during the study confirms the general trend observed in Svalbard and in many areas of the Arctic (Nørdli et al., 2014). In the years 
1997-2016 the average air temperature in the region during the summer season was $5.4^{\circ} \mathrm{C}$.

Glaciers of this region are polythermal (Sobota, 2009, 2011). Since their maximum extent in the late 19th and early 20th centuries to 2015, the total area of this region's valley glaciers has decreased on average by about $43 \%$ (Sobota et al., 2016). Waldemarbreen is an alpine-type glacier running down the valley towards Kaffiøyra. It contains one accumulation zone and a glacier tongue in the valley. The area of the glacier is $2.40 \mathrm{~km}^{2}$ (Sobota, 2017). It borders the Prins Heinrichfjella ridge in the north and east (500-770 $\mathrm{m}$ above sea level), and Gråfjellet (300-350 m) in the south. The glacier consists of two distinct parts separated by a medial moraine. The mean annual mass balance of the Waldemarbreen in 1996-2015 was $-0.72 \mathrm{~m}$ w.e. (Sobota et al., 2016), with very significant ablation in 2014. Since 1909, the glacier has been receding by $8 \mathrm{~m} \mathrm{a}^{-1}$. Between 1995 and 2009 the recession rate accelerated to $10 \mathrm{~m} \mathrm{a}^{-1}$, and between 2000 and 2009 reached $11 \mathrm{~m} \mathrm{a}^{-1}$ (Sobota and Lankauf, 2010). From the time of maximum advance to 2015 the Waldemarbreen area has decreased by $31.4 \%$ with an average annual recession of $8 \mathrm{~m} \mathrm{a}^{-1}$ (Sobota et al., 2016).

\subsection{Field campaign}

Sample locations are shown in Fig. 1. Soil samples were collected in 2009 (coded S01-S06). Sample sites represent accumulations of typical tundra. These areas are predominantly covered with dry moss and lichen tundra with communities of Saxifraga oppositifolia, Salix polaris, Sanionia uncinata, Luzula arcuata ssp. confusa, Cetrariella delisei, and Scorpidium revolvens (Sobota et al., 2018). Soil profiles S01S06 were collected at increasing distances from the front of Waldemarbreen (soil profile S06 was located on the flat outwash fan at the foreland of the moraine ridge of Aavatsmarkbreen). The profile depths varied from 12 to $17 \mathrm{~cm}$. All profiles were covered by a layer of organic material. Recovered soil cores were divided into $1-2 \mathrm{~cm}$ sub-samples and dried at $105^{\circ} \mathrm{C}$ to a constant weight, passed through a $2 \mathrm{~mm}$ sieve, and then prepared for radionuclide analysis. Additionally, 12 cryoconite samples (coded 2-13) were collected at Waldemarbreen in August-September 2014. The samples were taken from cryoconite holes at different altitudes, depths, and surface areas (see Table S1 in the Supplement). Material was collected with disposable plastic Pasteur pipettes and transferred to $15 \mathrm{~cm}^{3}$ plastic test tubes.

\subsection{Methods}

\subsubsection{Radionuclide analyses}

Gamma-emitting radionuclides $\left({ }^{137} \mathrm{Cs}\right.$ and $\left.{ }^{210} \mathrm{~Pb}\right)$ were measured by a planar HPGe (high-purity germanium) detector. The activities of ${ }^{137} \mathrm{Cs}$ were determined using its emission peak at $662 \mathrm{keV}$ and for ${ }^{210} \mathrm{~Pb} 46.6 \mathrm{keV}$ was used. Correc- tions were made for the effect of self-absorption of lowenergy $\gamma$-rays $(46.6 \mathrm{keV})$ within the sample, although these corrections were insignificant because of the very low sample weight ( 2 to $12 \mathrm{~g}$ ). The activities of ${ }^{238} \mathrm{Pu},{ }^{239+240} \mathrm{Pu}$, ${ }^{241} \mathrm{Am},{ }^{234,238} \mathrm{U}$, and ${ }^{230,232} \mathrm{Th}$ were determined for $0.5-$ $1.15 \mathrm{~g}$ cryoconite samples and $5 \mathrm{~g}$ dried soil samples. Organic matter contents were determined by loss on ignition (LOI) at $600^{\circ} \mathrm{C}$ for $6 \mathrm{~h}$. The samples were then dissolved using concentrated acids (HF, $\mathrm{HNO}_{3}, \mathrm{HCl}$ ). Details of the sequential radiochemical procedure used for determination of ${ }^{238} \mathrm{Pu},{ }^{239+240} \mathrm{Pu},{ }^{241} \mathrm{Am},{ }^{234,238} \mathrm{U}$, and ${ }^{230,232} \mathrm{Th}$ are described in previous publications (Łokas et al., 2010, 2018). The ${ }^{240} \mathrm{Pu} /{ }^{239} \mathrm{Pu}$ atom ratio was determined using Thermo Fisher Scientific Neptune multicollector inductively coupled plasma mass spectrometry (MC-ICP-MS; analytical method based on Taylor et al., 2001; Łokas et al., 2018). The combined measurement uncertainties of activity concentrations, which include counting statistics and counting efficiency uncertainties, are reported as $1 \sigma$. The Environmental Radioactivity Laboratory of the Henryk Niewodniczanski Institute of Nuclear Physics holds an ISO17025 accreditation for gamma-ray spectrometric measurements and $\mathrm{Pu}$ analyses by alpha-particle spectrometry.

\subsubsection{Heavy metal analyses}

Subsamples $(0.5 \mathrm{~g})$ were taken for measurement of selected heavy metals considered to be important anthropogenic contaminants $(\mathrm{Pb}, \mathrm{Cu}, \mathrm{Zn}, \mathrm{Cd})$. These metals and others $(\mathrm{Fe}$, $\mathrm{Al}, \mathrm{Ni}, \mathrm{Cr}, \mathrm{Mn}$ ) were measured by flame atomic absorption spectrometry (AAS Shimadzu 6800) using deuterium background correction. $\mathrm{Cd}$ and $\mathrm{Pb}$ stable isotope ratios were measured by ICP-MS (PerkinElmer SCIEX ELAN 9000). Measurement procedures are described in detail in Zaborska et al. (2017). Metal enrichment factors (EFs) were calculated according to the formula detailed in Zaborska et al. (2017). Mean background metal concentrations were taken from literature for the Hornsund region. The fraction of anthropogenic $\mathrm{Pb}\left(\mathrm{Pb}_{\text {ant }}\right)$ was calculated according to the formula detailed in Zaborska et al. (2017). The excess ${ }^{206} \mathrm{~Pb} /{ }^{207} \mathrm{~Pb}$ $\left({ }^{206} \mathrm{~Pb} /{ }^{207} \mathrm{~Pb}_{\text {excess }}\right)$ ratio calculation was used to source $\mathrm{Pb}$ pollution (Farmer et al., 1996; Bindler et al., 2001). The quality control and assurance for this method are presented in Zaborska et al. (2017).

\subsubsection{Statistical analyses}

Regression analysis was performed to find correlations between particular radionuclides and metal concentrations. The correlations characterized by $r>0.5$ are assumed to show moderate correlation, with $r>0.7$ indicating a strong correlation (e.g. Mukaka, 2012). The nonparametric Kruskal-Wallis test was used to observe the difference between radionuclide and metal concentrations in soil and cryoconite samples. All 


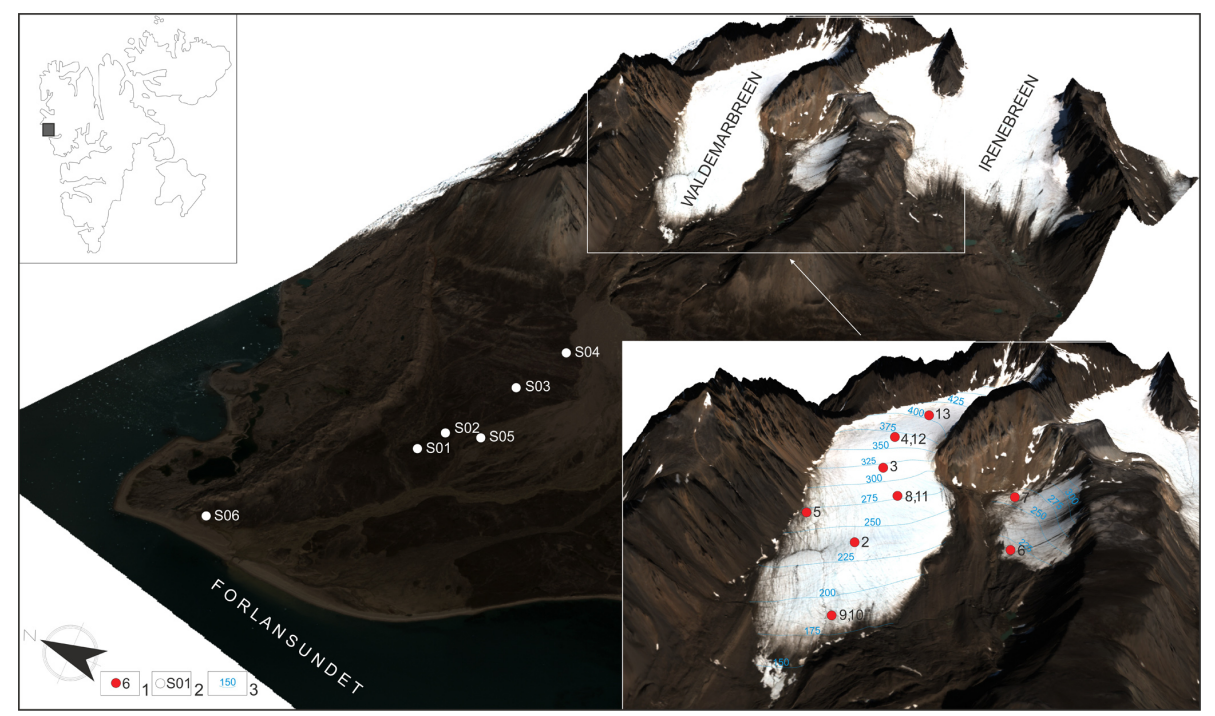

Figure 1. Study area location. Profiles S01-S06 were collected at increasing distances from the front of Waldemarbreen and cryoconite samples (2-13) from different altitudes of this glacier. Pleiades 1 satellite scene composite acquired in 31 July 2017 @CNES.

statistical calculations were performed using Statistica 10.0 (StatSoft, Inc., 2011).

\section{Results}

\subsection{Radionuclide contents and activity ratios in tundra soil profiles and cryoconite samples}

Activity concentrations and inventories of anthropogenic radionuclides $\left({ }^{137} \mathrm{Cs},{ }^{238} \mathrm{Pu},{ }^{239+240} \mathrm{Pu},{ }^{241} \mathrm{Am}\right)$ for tundra soil profiles and for cryoconite are shown in Table S2 and Fig. 2 and in Table S4 and Fig. 2, respectively. The radionuclide inventory is defined here as the activity of a given radionuclide contained in the soil column at unit surface area. Most of the profiles have concordant depth distributions of all artificial radionuclide activity with distinct peaks occurring in the surface or initial subsurface layers. The highest activity concentrations of anthropogenic radionuclides $\left(65 \pm 7 \mathrm{~Bq} \mathrm{~kg}^{-1}\right.$ for ${ }^{137} \mathrm{Cs}, 0.09 \pm 0.01 \mathrm{~Bq} \mathrm{~kg}^{-1}$ for ${ }^{238} \mathrm{Pu}, 2.13 \pm 0.16 \mathrm{~Bq} \mathrm{~kg}^{-1}$ for ${ }^{239+240} \mathrm{Pu}$, and $0.90 \pm 0.06 \mathrm{~Bq} \mathrm{~kg}^{-1}$ for ${ }^{241} \mathrm{Am}$ ) are observed in profile $\mathrm{S} 04$ at $1 \mathrm{~cm}$ depth where significant amounts of organic matter were observed (21\% LOI). Profile S02 shows no detectable ${ }^{137} \mathrm{Cs}$ (with a minimum detectable activity (MDC) range of 0.1 to $3 \mathrm{~Bq} \mathrm{~kg}^{-1}$ ). Activities of other radionuclides in this profile were not determined. In most samples activity concentrations of ${ }^{238} \mathrm{Pu}$ are close to the detection limit; consequently activity ratios of ${ }^{238} \mathrm{Pu} /{ }^{239+240} \mathrm{Pu}$ were calculated for only three samples. The maximum activity concentrations for cryoconite are $2000 \pm 300 \mathrm{~Bq} \mathrm{~kg}^{-1}$ for ${ }^{137} \mathrm{Cs}, 0.08 \pm 0.02$ to $2.1 \pm 0.2 \mathrm{~Bq} \mathrm{~kg}^{-1}$ for ${ }^{238} \mathrm{Pu}, 0.09 \pm 0.02$ to $43 \pm 3 \mathrm{~Bq} \mathrm{~kg}^{-1}$ for ${ }^{239+240} \mathrm{Pu}$, and $0.25 \pm 0.06$ to $25 \pm$ $2 \mathrm{~Bq} \mathrm{~kg}^{-1}$ for ${ }^{241} \mathrm{Am}$. All of these values are significantly higher than those observed in soil samples collected near this glacier.

The activity ratios of ${ }^{238} \mathrm{Pu} /{ }^{239+240} \mathrm{Pu},{ }^{239+240} \mathrm{Pu} /{ }^{137} \mathrm{Cs}$, and ${ }^{241} \mathrm{Am} /{ }^{239+240} \mathrm{Pu}$, as well as atom ratios of ${ }^{240} \mathrm{Pu} /{ }^{239} \mathrm{Pu}$, were calculated to potentially distinguish the sources of these radionuclides in tundra soils and cryoconite samples. The mean ${ }^{238} \mathrm{Pu} /{ }^{239+240} \mathrm{Pu}$ activity ratio for tundra is $0.039 \pm$ 0.010 , lower than for cryoconite at $0.050 \pm 0.009$. The analysis of atom ratios of ${ }^{240} \mathrm{Pu} /{ }^{239} \mathrm{Pu}$ provides important information which potentially allows a more precise identification of the origin of Pu isotopes. Average ${ }^{240} \mathrm{Pu} /{ }^{239} \mathrm{Pu}$ atom ratios in the tundra profiles were $0.178 \pm 0.003$ and $0.147 \pm 0.009$ in cryoconite. The mean ${ }^{239+240} \mathrm{Pu} /{ }^{137} \mathrm{Cs}$ activity ratio in tundra $(0.042 \pm 0.010)$ is higher than in the cryoconite samples $(0.020 \pm 0.004)$. Average ${ }^{241} \mathrm{Am} /{ }^{239+240} \mathrm{Pu}$ activity ratios for tundra and cryoconite were comparable $(0.46 \pm 0.07$ and $0.47 \pm 0.07$ ).

Average values of the radionuclide inventories calculated for all of these profiles are $0.66 \pm 0.14 \mathrm{~Bq} \mathrm{~m}^{-2}$ for ${ }^{238} \mathrm{Pu}, 20 \pm$ $2 \mathrm{~Bq} \mathrm{~m}^{-2}$ for ${ }^{239+240} \mathrm{Pu}, 9 \pm 1 \mathrm{~Bq} \mathrm{~m}^{-2}$ for ${ }^{241} \mathrm{Am}$, and $450 \pm$ $70 \mathrm{~Bq} \mathrm{~m}^{-2}$ for ${ }^{137} \mathrm{Cs}$.

Concentrations of the natural radioisotopes $\left({ }^{210} \mathrm{~Pb}\right.$, ${ }^{234,238} \mathrm{U},{ }^{230,232} \mathrm{Th}$ ) measured in the tundra soil profiles and cryoconite are shown in Table S3 and Table S5, respectively. Soil profile activity concentrations range from $15 \pm 1$ to $173 \pm$ $4 \mathrm{~Bq} \mathrm{~kg}^{-1}$ for total ${ }^{210} \mathrm{~Pb}, 13 \pm 1$ to $28 \pm 2 \mathrm{~Bq} \mathrm{~kg}^{-1}$ for ${ }^{234} \mathrm{U}$, $13 \pm 1$ to $30 \pm 2 \mathrm{~Bq} \mathrm{~kg}^{-1}$ for ${ }^{238} \mathrm{U}, 9 \pm 1$ to $22 \pm 2 \mathrm{~Bq} \mathrm{~kg}^{-1}$ for ${ }^{230} \mathrm{Th}$, and $8 \pm 1$ to $42 \pm 3 \mathrm{~Bq} \mathrm{~kg}^{-1}$ for ${ }^{232} \mathrm{Th}$. The highest activity concentration for ${ }^{210} \mathrm{~Pb}$ was found in the surface layer of profile S04 (concentration in cryoconite was $12300 \pm 600 \mathrm{~Bq} \mathrm{~kg}^{-1}$ ). Activity concentrations for $\mathrm{U}$ and $\mathrm{Th}$ isotopes in cryoconite samples are slightly higher than those 

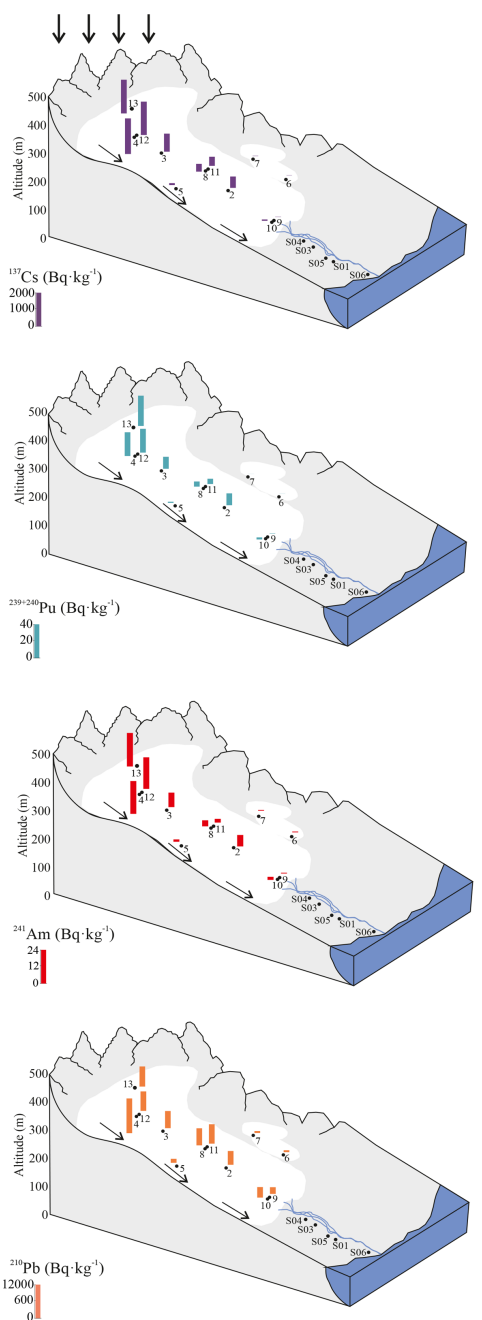

Figure 2. Schematic of Waldemarbreen with activity concentrations of atmospheric radionuclides $\left({ }^{210} \mathrm{~Pb},{ }^{137} \mathrm{Cs},{ }^{239,240} \mathrm{Pu},{ }^{241} \mathrm{Am}\right)$ in cryoconite and depth distribution in tundra soils.

in soils. ${ }^{234} \mathrm{U} /{ }^{238} \mathrm{U}$ activity ratios in soils and cryoconite are similar.

\subsection{Heavy metal analyses in tundra soil profiles and in cryoconite samples}

The concentrations of metals and stable $\mathrm{Pb}$ isotope ratios $\left({ }^{206} \mathrm{~Pb} /{ }^{207} \mathrm{~Pb},{ }^{208} \mathrm{~Pb} /{ }^{206} \mathrm{~Pb}\right)$ measured in soil and cryoconite samples are shown in Tables $\mathrm{S} 6$ and $\mathrm{S} 8$, respectively. $\mathrm{Pb}$ and $\mathrm{Cd}$ concentrations in soils and cryoconite are shown in Fig. 3. $\mathrm{Pb}$ concentrations varied from 9.6 to $25.9 \mathrm{mg} \mathrm{kg}^{-1}$. Cd concentrations range from 0.05 to $0.6 \mathrm{mg} \mathrm{kg}^{-1}, \mathrm{Zn}$ concentrations range from 45.1 to $76.9 \mathrm{mg} \mathrm{kg}^{-1}$, and $\mathrm{Cu}$ concentrations range from 11.8 to $26.6 \mathrm{mg} \mathrm{kg}^{-1}$. The concentrations in cryoconite were significantly higher than in soils. $\mathrm{Pb}$ concentrations ranged from 19.9 to $97.7 \mathrm{mg} \mathrm{kg}^{-1}$. Cd concentrations varied from 0.2 to $0.6 \mathrm{mg} \mathrm{kg}^{-1}, \mathrm{Zn}$ concentrations ranged from 59.6 to $97.5 \mathrm{mg} \mathrm{kg}^{-1}$, and $\mathrm{Cu}$ concentrations

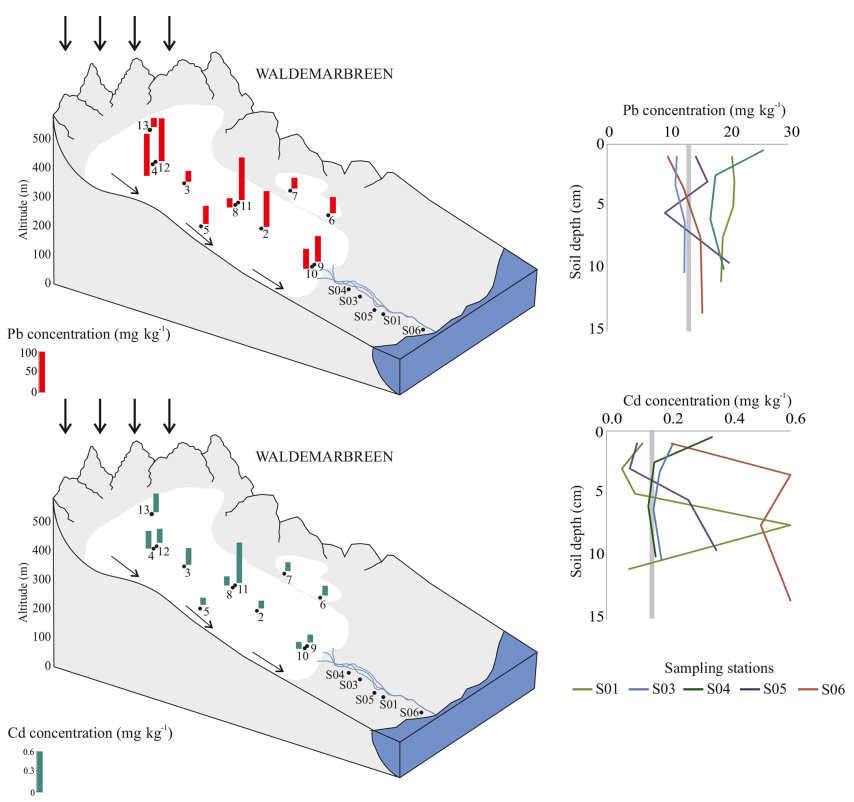

Figure 3. Concentrations of selected heavy metals $(\mathrm{Pb}, \mathrm{Cd})$ in cryoconite samples and tundra soil profiles.

ranged from 21.5 to $40.1 \mathrm{mg} \mathrm{kg}^{-1} \cdot{ }^{206} \mathrm{~Pb} /{ }^{207} \mathrm{~Pb}$ measured in soils ranged from 1.190 to 1.217 while ${ }^{208} \mathrm{~Pb} /{ }^{206} \mathrm{~Pb}$ ranged from 2.014 to 2.057; cryoconite values are very similar, ranging from 1.169 to 1.199 for ${ }^{206} \mathrm{~Pb} /{ }^{207} \mathrm{~Pb}$ and 2.025 to 2.061 for ${ }^{208} \mathrm{~Pb} /{ }^{206} \mathrm{~Pb}$. There was a significant correlation between $\mathrm{Pb}$ and $\mathrm{Cu}$ and $\mathrm{Zn}(r=0.82, r=0.71)$ in soils (Table S7) and cryoconite $(r=0.78)$ (Table $\mathrm{S} 9)$. $\mathrm{Pb}$ also correlated with naturally derived metals $\mathrm{Ni}$ and $\mathrm{Co}(r=0.48-0.59)$ in soils and in cryoconite $\mathrm{Ni}(r=0.67)$. Cu correlated with $\mathrm{Zn}(r=0.77)$ only in soils. Interestingly, Cd did not correlate with any of these metals in soils or cryoconite. Correlations between contaminating heavy metals and soil composition markers $\mathrm{Fe}$ and $\mathrm{Al}$ were assessed to test the influence of the natural variability of soil composition on metal concentration. Generally, there was no significant correlation in soils or cryoconite. The metal enrichment factors (normalized to $\mathrm{Al}$ ) are generally comparable for soil and cryoconite samples and ranged from 1.1 to 1.8 for $\mathrm{Pb}$, from 0.9 to 1.6 for $\mathrm{Zn}$, from 0.8 to 2.1 for $\mathrm{Cu}$, from 0.4 to 7.7 for $\mathrm{Cd}$ (Table S6), from 1.5 to 6.1 for $\mathrm{Pb}$, from 1.0 to 1.5 for $\mathrm{Zn}$, from 1.3 to 2.3 for $\mathrm{Cu}$, and from 0.5 to 4.5 for Cd (Table S8). For most metals there were significant differences in concentrations observed in the soil and cryoconite samples (Table S10). The only exception is $\mathrm{Cd}$, which was similar (and elevated) in both environments. There was no difference in ${ }^{208} \mathrm{~Pb} /{ }^{206} \mathrm{~Pb}$ in soil and cryoconite samples. This is not surprising as this measure is less specific than ${ }^{206} \mathrm{~Pb} /{ }^{207} \mathrm{~Pb}$ (the ${ }^{208} \mathrm{~Pb} /{ }^{206} \mathrm{~Pb}$ coal burning signature has a ratio similar to a natural rock). 


\section{Discussion}

\subsection{Radionuclides and heavy metal contamination}

All soil profiles show activity concentrations and inventories typical of raised marine terraces covered by dry tundra in the western part of Spitsbergen (Łokas et al., 2014, 2017a, b; AMAP, 2015; Dowdall et al., 2003; Gwynn et al., 2004; Hardy et al., 1973). Retention of airborne radionuclides in tundra soils is facilitated by the presence of a well-developed organic horizon.

Cryoconite materials are highly enriched with atmospheric radionuclides compared to tundra soils. This enrichment can be explained to some extent by the focusing of fine-grained material, washed down into very small depressions where the cryoconite samples were collected, and also by the properties of cryoconite material. Cryoconite granules are mixtures of mineral particles, organic matter, and microorganisms, which can retain and concentrate airborne radionuclides due to the metal-binding properties of extracellular substances that are excreted by microorganisms (Gadd, 2004; Francis, 2007). Differences in activity concentrations of anthropogenic radionuclides $\left({ }^{137} \mathrm{Cs}\right.$, Pu isotopes, and $\left.{ }^{241} \mathrm{Am}\right)$ found among the cryoconite samples reflect the different locations of sampling sites, morphological features, and organic material content. A significant correlation was observed between the amount of organic matter present and the concentration of all airborne radionuclides $(r=0.79-0.83)$. We also note a significant correlation between ${ }^{210} \mathrm{~Pb},{ }^{137} \mathrm{Cs}$, $\mathrm{Pu}$ isotopes, and ${ }^{241} \mathrm{Am}$ with altitude $(r=0.64-0.91)$ and the location of the cryoconite holes $(r=0.58-0.63)$. This is not the case for ${ }^{210} \mathrm{~Pb}(r=0.38)$. Cryoconite hole depth correlates with ${ }^{210} \mathrm{~Pb}$ and Pu isotopes ( $\left.r=0.60-0.68\right)$ (Table S8). Cryoconite samples collected at the highest locations $(4,12,13)$ with the largest hole surface area (Table S1) were characterized by the highest observed activity concentrations. These three points were located close to each other so the material deposited could have originated from the same source and migrated with supraglacial streams. In contrast, sampling points 5,6 , and 7 , which were located close to the moraine at lower altitude, were characterized by the lowest activity concentrations of anthropogenic radionuclides. These materials could have been washed out or mixed with mineral particles from the moraine. The highest ${ }^{210} \mathrm{~Pb}$ activity concentration was observed in sample $4\left(>12000 \mathrm{~Bq} \mathrm{~kg}^{-1}\right)$. More uniform and comparable values $\left(\sim 5000 \mathrm{~Bq} \mathrm{~kg}^{-1}\right)$ were found in cryoconite samples $3,8,11,12$, and 13 . This ${ }^{210} \mathrm{~Pb}$ distribution is very similar to the distribution of anthropogenic radionuclides. Cryoconite granules can be locally redistributed on the surface of ice, depending on glacier morphology and altitude. It was noted that activity concentrations increase in relation to the altitude. Material deposited in the highest locations can migrate with supraglacial streams and be transported along with the glacier. Samples 4 and 13 were collected from typical cryoconite holes with the largest surface area (476 and $1200 \mathrm{~cm}^{2}$ ) (Table S1). Regardless of the lifespan of individual cryoconite holes, their collapse does not imply removal of cryoconite from glacier surface as the dispersed cryoconite granules initiate formation of new holes (Takeuchi et al., 2001a, b).

The constant delivery of ${ }^{210} \mathrm{~Pb}$ from the atmosphere suggests that the concentration of this radionuclide in cryoconite material should be proportional to the exposure time, while high concentrations of the artificial radionuclides indicate a significant contribution of material that was exposed to stratospheric or tropospheric fallout. The results show that ${ }^{210} \mathrm{~Pb}$ is being deposited at a more constant rate; lower values for samples 3, 8,11,12, and 13 may suggest that the majority of the material was already removed with meltwater or that material in these samples is younger than in sample 4 (thereby having had less contact time with the atmosphere).

The effect of glacial morphology on effective trapping and storing of radionuclides was also observed in the Georgia glacier (Łokas et al., 2018). The differences in radionuclide concentrations between sampling points and the lack of clear differences in the elevation gradient from terminus towards icefall may reflect the heterogeneous topography of the glacier tongue. In the Waldemarbreen we observed differences in the elevation gradient from the top of the ice.

Activity concentrations of ${ }^{234,238} \mathrm{U}$ and ${ }^{230,232} \mathrm{Th}$ show little variability within the profiles and do not differ from values reported for soils globally (UNSCEAR, 1993), in the tundra soils in northern Spitsbergen (Dowdall et al., 2003) and in southwestern Spitsbergen (Łokas et al., 2017b). Soil activity concentrations of lithogenic radionuclides are related to their source minerals and are not influenced by the action of cryoconite. The presence of $U$ and $T h$ is the main contributor to natural terrestrial radioactivity. $\mathrm{U}$ isotopes $\left({ }^{234} \mathrm{U}\right.$ and $\left.{ }^{238} \mathrm{U}\right)$ in terrestrial samples (rocks, soils, and sediments) are usually present in radioactive equilibrium. The main sources of $\mathrm{U}$ in the natural environment are atmospheric precipitation of terrigenous material, soil resuspension, and rock weathering.

Our data for $\mathrm{U}$ and $\mathrm{Th}$ in cryoconite samples are comparable to other reported data. Our previous paper (Lokas et al., 2018) showed similar results in cryoconite granules from the Georgia glacier, while on a Swiss glacier (Baccolo et al., 2017), ${ }^{238} \mathrm{U}$ and ${ }^{230} \mathrm{Th}$ are higher. The ${ }^{234} \mathrm{U} /{ }^{238} \mathrm{U}$ activity ratio measured in cryoconite granules suggests a state of radioactive equilibrium. The ${ }^{230} \mathrm{Th} /{ }^{232} \mathrm{Th}$ activity ratio in cryoconite varies from 0.4 to 0.7 . In only a few samples the activity ratio of ${ }^{230} \mathrm{Th} /{ }^{232} \mathrm{Th}$ is about 1 (samples $2,3,4,12$, 13). Isotopes derived from $U\left({ }^{230} \mathrm{Th}\right)$ and $\mathrm{Th}$ series $\left({ }^{232} \mathrm{Th}\right)$ are not correlated in cryoconite samples $(r=0.36)$ but are better correlated $(r=0.80)$ in tundra soil profiles. This may suggest that Th from the U series is removed with meltwater from cryoconite samples located at the top of the glacier. We also observed differences in $\mathrm{U}$ and Th activity concentrations in tundra soils and cryoconite samples, with tundra soils having lower values than in cryoconite. 
The metal concentrations found in soils were typical or slightly higher than natural background levels. This is confirmed by generally low metal enrichment factors (EFs), with the exception of $\mathrm{Cd}$. Metal distributions measured in this study are very similar to those of parent rocks (natural crust) in Spitsbergen. Rocks in Hornsund contain very low concentrations of heavy metals $(\mathrm{Pb} \sim$ $11 \mathrm{mg} \mathrm{kg}^{-1}, \mathrm{Cd} \sim 0.04 \mathrm{mg} \mathrm{kg}^{-1}, \mathrm{Zn} \sim 58 \mathrm{mg} \mathrm{kg}^{-1}, \mathrm{Cu} \sim$ $20 \mathrm{mg} \mathrm{kg}^{-1}$; Samecka-Cymerman et al., 2011). Enrichment in $\mathrm{Cd}$ and $\mathrm{Pb}$ was found in surface and subsurface soil profile layers (Fig. 3). Similar enrichments ( $\mathrm{Pb}$ up to $25.3 \mathrm{mg} \mathrm{kg}^{-1}$, $\mathrm{Cd}$ up to $0.4 \mathrm{mg} \mathrm{kg}^{-1}$ ) in soil profiles of Kaffiøyra were found in the 1980s by Plichta and Kuczyńska (1991). Generally low metal concentrations have been mapped by Ottesen et al. (2010) in alluvial soils in the Kaffiøyra region. Alluvial sediments are believed to represent natural metal levels, although recently deposited layers can be polluted by anthropogenic activity; $\mathrm{Cd}$ concentrations range from 0.01 to $0.13 \mathrm{mg} \mathrm{kg}^{-1}, \mathrm{Cu}$ from 13.4 to $43.4 \mathrm{mg} \mathrm{kg}^{-1}, \mathrm{~Pb}$ from 8.9 to $24.3 \mathrm{mg} \mathrm{kg}^{-1}$, and $\mathrm{Zn}$ from 58.9 to $79.2 \mathrm{mg} \mathrm{kg}^{-1}$. Metal concentrations were studied in peat cores collected from nearby Kongsfjorden. $\mathrm{Cu}$ ranged from 7 to $25 \mathrm{mg} \mathrm{kg}^{-1}, \mathrm{~Pb}$ from 10 to $35 \mathrm{mg} \mathrm{kg}^{-1}$, and $\mathrm{Zn}$ from 20 to $75 \mathrm{mg} \mathrm{kg}^{-1}$ (Headley, 1996). The Kongsfjorden region might have been impacted by former mining activity, however (Hao et al., 2013). More recently, the metal distribution in soils of other Spitsbergen regions (Kongsfjorden and Adventfjorden) was studied by Halbach et al. (2017). Like our study, they found elevated concentrations of some metals, e.g. Cd (0.13-1.00 mg kg$\left.{ }^{-1}\right)$, in surface soils (covered by moss), but low concentrations of metals $\left(\mathrm{Cd}=0.04-0.5, \mathrm{Cu}=3.3-28.4 \mathrm{mg} \mathrm{kg}^{-1}, \mathrm{~Pb}=2.9-\right.$ $22.7 \mathrm{mg} \mathrm{kg}^{-1}$, and $\mathrm{Zn}=25-106 \mathrm{mg} \mathrm{kg}^{-1}$ ) in the sandy fraction of soils (sampled at $20 \mathrm{~cm}$ depth). Slightly higher levels of metals ( $\mathrm{Cu}: 17-92 \mathrm{mg} \mathrm{kg}^{-1}$ and $\mathrm{Cd}: 0.05-1.20 \mathrm{mg} \mathrm{kg}^{-1}$ ) were measured in biologically rich soils in the Hornsund region with the highest values in areas of rich vegetation (Wojtuń et al., 2013). Ziółek et al. (2017) report much higher metal concentrations in peat soils in Bellsund. In their study $\mathrm{Pb}$ reached $100 \mathrm{mg} \mathrm{kg}^{-1}, \mathrm{Zn}$ reached $140 \mathrm{mg} \mathrm{kg}^{-1}, \mathrm{Cu} 57$ reached $\mathrm{mg} \mathrm{kg}^{-1}$, and $\mathrm{Cd}$ reached $8 \mathrm{mg} \mathrm{kg}^{-1}$. In these cases the contamination of peat soils was caused by depositions of organic matter from a bird colony. In conclusion, an anthropogenic influence on soils in the Kaffiøyra region was limited.

While soils can receive metals from the atmosphere and from the surface run-off, cryoconites are fed only by atmospheric particles. Thus, interestingly, metal concentrations in cryoconite were higher than in soil samples (Table S8) and significantly exceeded natural values. Particularly elevated were the concentrations of $\mathrm{Pb}$ and $\mathrm{Cd}$. The enrichment of other metals was lower $(\mathrm{Zn}$ and $\mathrm{Cu})$. The maximum concentration of $\mathrm{Pb}$ in cryoconite samples from Hansbreen in Hornsund was lower $\left(82.7 \mathrm{~m} \mathrm{~kg}^{-1}\right)$, but the concentrations of $\mathrm{Zn}\left(108 \mathrm{mg} \mathrm{kg}^{-1}\right)$ and $\mathrm{Cd}\left(1.53 \mathrm{mg} \mathrm{kg}^{-1}\right)$ were higher, however (Łokas et al., 2016). Singh et al. (2013) found a similar range of metal concentrations in cryoconite samples from a glacier located in the Kongsfjorden area $(\mathrm{Pb}$ up to $85.1 \mathrm{mg} \mathrm{kg}^{-1}, \mathrm{Cu}$ up to $44 \mathrm{mg} \mathrm{kg}^{-1}, \mathrm{Cd}$ up to $0.14 \mathrm{mg} \mathrm{kg}^{-1}$, $\mathrm{Zn}$ up to $150 \mathrm{mg} \mathrm{kg}^{-1}$ ). Chmiel et al. (2009) did not find elevated metal levels in glacier waters in the Scott Glacier in Bellsund, but they did report enrichment in some metals $\left(\mathrm{Pb}=190 \mathrm{mg} \mathrm{kg}^{-1}\right)$ in cryogenic sediments.

\subsection{The source of radionuclides and heavy metal contamination}

Activity ratios of ${ }^{238} \mathrm{Pu} /{ }^{239+240} \mathrm{Pu}, \quad{ }^{239+240} \mathrm{Pu} /{ }^{137} \mathrm{Cs}$ ${ }^{241} \mathrm{Am} /{ }^{239+240} \mathrm{Pu}$, and ${ }^{240} \mathrm{Pu} /{ }^{239} \mathrm{Pu}$ atom are commonly used to identify and distinguish between global (stratospheric) and regional (tropospheric) sources of these radionuclides (Oughton et al., 2004; Hirose and Povinec, 2015; Łokas et al., 2013, 2014, 2016, 2017b).

${ }^{238} \mathrm{Pu} /{ }^{239+240} \mathrm{Pu}$ activity ratios in cryoconite samples are consistently higher than in tundra soils, suggesting a contribution from sources other than the global $\mathrm{Pu}$ fallout in this region. The proportion of global fallout versus local sources was modelled assuming that the ${ }^{238} \mathrm{Pu} /{ }^{239+240} \mathrm{Pu}$ activity ratios for global fallout and Chernobyl plutonium are about 0.025 and 0.24 , respectively. The following formula described by Mietelski and Wąs (1995) was used:

$f_{\mathrm{G}}=\left(A_{\mathrm{R}}-A_{\mathrm{M}}\right) /\left(A_{\mathrm{R}}-A_{\mathrm{G}}\right)$,

where $f_{\mathrm{G}}$ represents the fraction of plutonium isotopes from global fallout sources $(\%), A_{\mathrm{R}}$ represents the ${ }^{238} \mathrm{Pu} /{ }^{239+240} \mathrm{Pu}$ ratio of Chernobyl sources $(0.24), A_{\mathrm{M}}$ represents the measured ${ }^{238} \mathrm{Pu} /{ }^{239+240} \mathrm{Pu}$ activity ratio in cryoconite samples, and $A_{G}$ represents the ${ }^{238} \mathrm{Pu} /{ }^{239+240} \mathrm{Pu}$ activity ratio of global fallout (0.025).

Calculations were performed for each of the studied cryoconite samples; the fraction of global fallout varied from $82 \pm 1 \%$ to $97 \pm 1 \%$ (Fig. 4). Samples 4, 8, and 12, with the highest activity ratios of ${ }^{238} \mathrm{Pu} /{ }^{239+240} \mathrm{Pu}(0.062)$, also contained the highest contribution of Pu from other sources (18\% and $17 \%$, respectively). The highest activity ratios of ${ }^{238} \mathrm{Pu} /{ }^{239+240} \mathrm{Pu}(0.075$ to 0.09$)$ were observed in the initial soils from the vicinity of the Werenskiold glacier terminus in the southwestern part of Spitsbergen. These values fall within the range found for cryoconite from the Hans glacier (with a mean of 0.064) and other Arctic glaciers (Łokas et al., 2016; unpublished data) (Fig. 5a). The ${ }^{240} \mathrm{Pu} /{ }^{239} \mathrm{Pu}$ atom ratios measured in tundra soils (average of 0.179) (Fig. 5b) are comparable to global fallout ratios $(0.183 \pm 0.009)$ reported by Efurd et al. (2005) at $70^{\circ} \mathrm{N}$ latitude and 0.180 reported by others (Muramatsu et al., 1999; Warneke et al., 2002). Similar results were reported for tundra soils from Spitsbergen (80 samples) with an average value of 0.179 (Eokas et al., 2017a). Thus, the tundra sites exposed to the atmosphere over the whole period of anthropogenic radionuclide release acquired their radionuclide contents primarily from direct atmospheric deposition. 
(a) GLOBAL FALLOUT PU

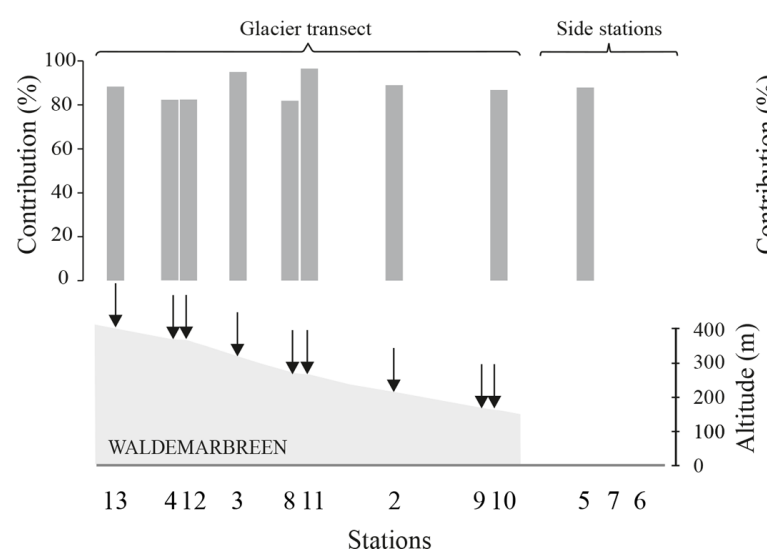

(b) ANTHROPOGENIC PB

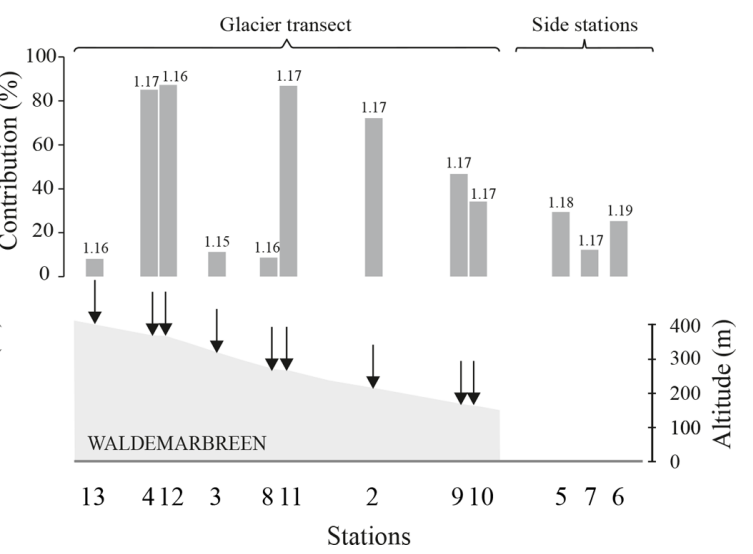

Figure 4. (a) The contribution of global fallout $\mathrm{Pu}$ calculated using plutonium isotope ratios and (b) contribution of anthropogenic origin $\mathrm{Pb}$ calculated using $\mathrm{Pb}$ isotopes and the end-member method.

In tundra soils, ${ }^{240} \mathrm{Pu} /{ }^{239} \mathrm{Pu}$ atom ratios and the ${ }^{238} \mathrm{Pu} /{ }^{239+240} \mathrm{Pu}$ activity ratios are similar to the global fallout signature ( 0.180 and 0.025 , respectively); however, in the cryoconite samples measured in this study (and other unpublished data from Arctic cryoconite) they are lower (0.147 and 0.050 , respectively) (see Fig. 5a, b). Due to the slow accumulation of tundra soils and their continuous exposure to the atmosphere, the vertical profiles of the fallout radionuclides represent their time-averaged deposition on the soil surface. In contrast, different cryoconite samples from the same glacier could be exposed to fallout for various periods resulting in preferential uptake of radionuclides from single deposition events and deviations from the global fallout signatures. In a previous article (Łokas et al., 2017a) we assumed that the main sources of $\mathrm{Pu}$ in the proglacial soils (and now also in cryoconite samples) were nuclear tests and nonexploded weapons-grade material. The lack of correlation between excess ${ }^{238} \mathrm{Pu}$ and ${ }^{240} \mathrm{Pu} /{ }^{239} \mathrm{Pu}$ atom ratios (Fig. 5c) suggests that the excessive ${ }^{238} \mathrm{Pu}$ is derived from sources other than ${ }^{239} \mathrm{Pu}$, such as pure ${ }^{238} \mathrm{Pu}$ from the SNAP9A satellite re-entry (Corcho Alvarado et al., 2014). A similar ${ }^{238} \mathrm{Pu}$ enrichment was observed in other cryoconite samples from Arctic glaciers (unpublished data) (Fig. 5c) and in air filters in Finland (Salminen-Paatero et al., 2012) and NW Poland (Kierepko et al., 2016).

The average ${ }^{239+240} \mathrm{Pu} /{ }^{137} \mathrm{Cs}$ ratios in tundra soils (0.042) are similar to the global fallout value (0.039) expected for the year 2013 (UNSCEAR, 1982); in cryoconite samples (0.020) it is lower. The observed average of about $0.021 \pm 0.03$ in the proglacial zone of the glacier from west Spitsbergen is remarkable as there were no other values as low as at this site. Similar or slightly higher values $(0.021-0.035)$ were observed on Spitsbergen by Gwynn et al. (2004) and Łokas et al. (2014). The enrichment of soils in ${ }^{137} \mathrm{Cs}$ relative to plutonium might be due to the contributions from sources other than global fallout or these ratios may actually reflect the de- position ratios at this latitude. The mean ${ }^{241} \mathrm{Am} /{ }^{239+240} \mathrm{Pu}$ ratios for tundra soils (0.47) and cryoconite samples (0.46) fall within the ranges reported for soils from western Spitsbergen (Łokas et al., 2014, 2013) and other Arctic sites (Holm et al., 1983; Smith et al., 1995; Gwynn et al., 2005).

The relatively high ${ }^{206} \mathrm{~Pb} /{ }^{207} \mathrm{~Pb}$ ratio $(1.190-1.217)$ measured in Kaffiøyra soils is close to the natural ratio for parent rocks $(>1.215)$ and/or represents a mixture of natural and anthropogenic $\mathrm{Pb}$ sources (Zaborska et al., 2017). The metallic trace elements, which are transported in the atmosphere attached to airborne particulate matter, tend to be retained and concentrated in the cryoconite material. This finding is confirmed by relatively lower ${ }^{206} \mathrm{~Pb} /{ }^{207} \mathrm{~Pb}$ ratios in cryoconite samples. These ratios suggested that $\mathrm{Pb}$ in cryoconite is a mixture of natural and anthropogenic sources and that anthropogenic $\mathrm{Pb}$ origin prevails. Using the endmember method and based on stable $\mathrm{Pb}$ isotope ratios, the contribution of anthropogenically derived $\mathrm{Pb}$ was estimated in cryoconite. It was found that anthropogenic $\mathrm{Pb}$ constituted $10 \%-100 \%$ of the $\mathrm{Pb}$ accumulated in cryoconite samples (Fig. 4). In the case of the Horsund site (Hansbreen) the anthropogenic lead fraction in cryoconite was lower and ranged from $29 \%$ to $95 \%$ (Łokas et al., 2016). It was also calculated that the excess $\mathrm{Pb}$ in cryoconite material $\left(\mathrm{Pb}_{\text {measured }}-\right.$ $\left.\mathrm{Pb}_{\text {natural }}\right)$, was characterized by ${ }^{206} \mathrm{~Pb} /{ }^{207} \mathrm{~Pb}$ of $1.156-1.189$ (Fig. 4). Side stations located closer to rocky glacier sides were characterized by higher (more natural) calculated anthropogenic $\mathrm{Pb}$ isotopic ratios (1.17-1.19) compared to stations located in the central transect of the glacier (1.16-1.17). Since glaciers are fed by airborne particles ${ }^{206} \mathrm{~Pb} /{ }^{207} \mathrm{~Pb}$ ratios in cryoconite can be compared to aerosol ${ }^{206} \mathrm{~Pb} /{ }^{207} \mathrm{~Pb}$. The study of aerosols in the Kongsfjorden region recognized the dominance of two sources of $\mathrm{Pb}$. In the spring, isotope signatures of ${ }^{206} \mathrm{~Pb} /{ }^{207} \mathrm{~Pb}$ of $\sim 1.158$ suggest an eastern Eurasian source, while in the summer a signature of ${ }^{206} \mathrm{~Pb} /{ }^{207} \mathrm{~Pb}$ of $\sim 1.167$ suggests a mixture of North Amer- 

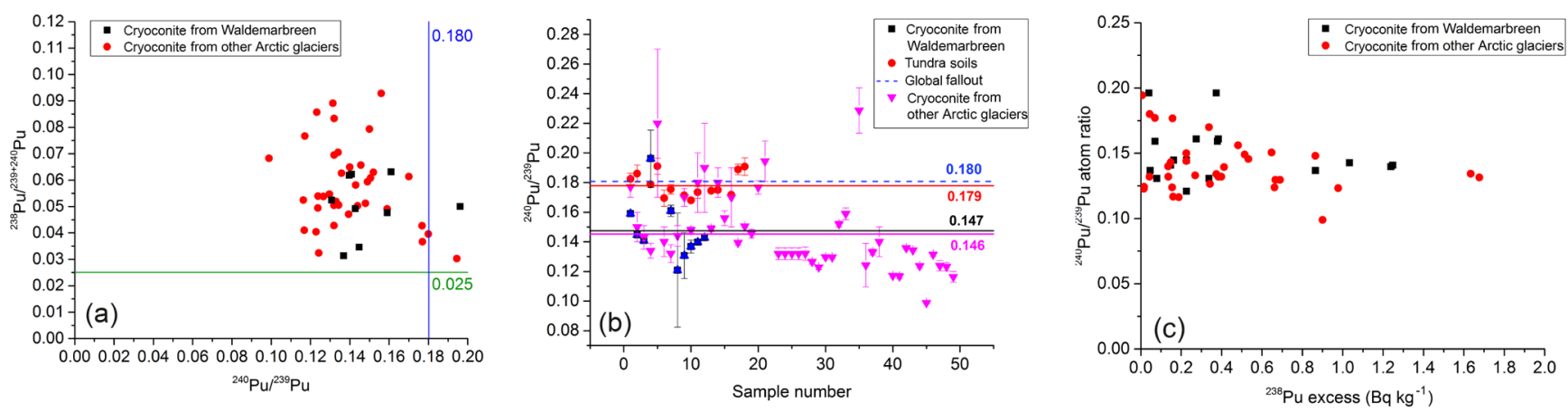

Figure 5. The relationship between ${ }^{240} \mathrm{Pu} /{ }^{239} \mathrm{Pu}$ atom ratios and ${ }^{238} \mathrm{Pu} /{ }^{239+240} \mathrm{Pu}$ activity ratios in cryoconite samples from this study and other Arctic cryoconite (unpublished data) (a); the relationship between ${ }^{240} \mathrm{Pu} /{ }^{239} \mathrm{Pu}$ atom ratio and sample number in tundra soils, cryoconite samples (this study), and other Arctic cryoconite (unpublished data) (b); the correlation between excess ${ }^{238} \mathrm{Pu}$ and ${ }^{240} \mathrm{Pu} /{ }^{239} \mathrm{Pu}$ atom ratios in cryoconite samples (this study) and other Arctic cryoconite (unpublished data) (c).

ican and Eurasian influence (Bazzano et al., 2015). Thus, the cryoconite ${ }^{206} \mathrm{~Pb} /{ }^{207} \mathrm{~Pb}$ ratios compare well with aerosol ${ }^{206} \mathrm{~Pb} /{ }^{207} \mathrm{~Pb}$, particularly in the centre part of the glacier. This implies that it is mostly anthropogenic and not natural $\mathrm{Pb}$ that accumulates in the cryoconite samples and it can be said that an anthropogenic environmental impact is clearly visible in the Spitsbergen cryosphere.

Both radionuclides and heavy metals are deposited from the atmosphere on land, ocean, and glacier surfaces by wet and dry precipitation. Since there are no new sources of radioactive pollution in the atmosphere, the patterns of atmospheric circulation do not influence radionuclide distribution on different glaciers on Svalbard. The amount of precipitation received by the glacier can definitely influence the glacier pollution since coastal areas (e.g. Kaffiøyra) receive twice the amount received in inland areas (Førland et al., 2011). Post-depositional processes, mainly those connected to cryoconite hole formation and eventual material transport within the glacier, appear to have a more significant influence on the levels of radionuclide pollution within the glacier. A different scenario concerns the distribution of heavy metals. Since they are still emitted to the atmosphere from different sources, the direction of atmospheric circulation is an important factor shaping their distribution within the glacier. The primary atmospheric metal discharge originates from Europe and Russia (Isaksen et al., 2016). In coastal regions local winds can enhance the introduction of contaminants due to transport of contaminated sea salt aerosols (Lüdke et al., 2005 Kozak et al., 2015).

\section{Conclusions}

The extent of variations in activity concentrations of airborne radionuclides and some trace metals $(\mathrm{Pb}$ and $\mathrm{Cd})$ in cryoconite samples from Waldemarbreen exceeds ranges observed in soils surrounding this glacier. The mechanisms responsible for accumulation of atmospheric contaminates are not clear but we observed the effect of glacial morphology on trapping and storing of airborne radionuclides. The average atom ratios of ${ }^{240} \mathrm{Pu} /{ }^{239} \mathrm{Pu}$ for tundra soils are comparable to the characteristic ratio for global fallout, but for cryoconite samples $(0.147)$ they are lower than for surrounding soils and also for other initial soils from the west coast of Spitsbergen. We observed an excess of ${ }^{238} \mathrm{Pu}$ in cryoconite samples similar to that observed in other initial soils in Spitsbergen. This enrichment of ${ }^{238} \mathrm{Pu}$ is likely derived from sources other than ${ }^{239} \mathrm{Pu}$. This could be derived from pure ${ }^{238} \mathrm{Pu}$ from a satellite re-entry after injection from the stratosphere into the troposphere. Monitoring of cryoconite samples permits the identification of $\mathrm{Pu}$ release events in the form of a fallout associated with each separate event. Therefore, cryoconite is an excellent candidate for atmospheric contamination monitoring. The lithogenic radionuclide contents vary in much narrower ranges and their variability reflects changing proportions of weathering products derived from diverse parent rocks.

Data availability. All raw research data are presented in the Supplement.

Supplement. Full data about environmental radioactivity are available in the Supplement. The supplement related to this article is available online at: https://doi.org/10.5194/tc-13-2075-2019supplement.

Author contributions. E€ designed the idea of this study and performed gamma and alpha analyses. AC prepared the calibration for gamma analyses. PK performed uranium analyses. IS collected the soil and cryoconite samples. PG carried out the purification of $\mathrm{Nd}(\mathrm{Pu}) \mathrm{F}_{3}$ alpha-spectrometric sources in preparation for MC-ICPMS measurements and helped with language improvement. JAM carried out MC-ICP-MS analysis. EŁ and AZ wrote the paper. EŁ, AZ, PG, and IS supervised the research and contributed to the interpretation of the data. JAM made some language corrections. 
Competing interests. The authors declare that they have no competing interests (both financial or non-financial).

Financial support. This research has been supported by the Polish National Science Center (grant no. 2016/21/B/ST10/02327) and IFJ PAS statutory research resources.

Review statement. This paper was edited by Mark Flanner and reviewed by two anonymous referees.

\section{References}

AMAP Assessment Report: Radioactivity in the Arctic, Oslo, Norway, 2015.

Baccolo, G., Di Mauro, B., Massabò, D., Clemenza, M., Nastasi, M., Delmonte, B., Prata, M., Prati, P., Previtali, E., and Maggi, V.: Cryoconite as a temporary sink for anthropogenic species stored in glaciers, Sci. Rep., 7, 9623, https://doi.org/10.1038/s41598-017-10220-5, 2017.

Barbante, C., Schwikowski, M., Döring, T., Gäggeler, H. W., Schotterer, U., Tobler, L., van de Velde, K., Ferrari, C., Cozzi, G., Turetta, A., Rosman, K., Bolshov, M., Capodaglio, G., Cescon, P., and Boutron, C.: Historical record of European emissions of heavy metals to the atmosphere since the 1650 s from alpine snow/ice cores drilled near Monte Rosa, Environ. Sci. Technol., 38, 4085-4090, 2004.

Bazzano, A., Ardini, F., Becagli, S., Traversi, R., Udistri, R., Cappelletti, D., and Grotti, M.: Source assessment of atmospheric lead measured at Ny-Ålesund, Svalbard, Atmos. Environ., 113, 20-26, https://doi.org/10.1016/j.atmosenv.2015.04.053, 2015.

Bindler, R., Renberg, I., Anderson, N. J., Appleby, P. G., Emteryd, O., and Boyle, J.: Pb isotope ratios of lake sediments in West Greenland: interferences on pollution sources, Atmos. Environ., 35, 4675-4685, https://doi.org/10.1016/S1352-2310(01)001157, 2001.

Chmiel, S., Reszka, M., and Rysiak, A.: Heavy metals and radioactivity in environmental samples of the Scott Glacier region, Quaestiones Geographicae, 1, 23-29, 2009.

Cook, J. M., Edwards, A., Takeuchi, N., and Irvine-Fynn, T.: Cryoconite. The dark biological secret of the cryosphere, Prog. Phys. Geogr., 40, 1-46, https://doi.org/10.1177/0309133315616574, 2015.

Cook, J. M., Edwards, A., Bulling, M., Mur, L. A., Cook, S., Gokul, J. K., Cameron, K. A., Sweet, M., and Irvine-Fynn, T. D.: Metabolome-mediated biocryomorphic evolution promotes carbon fixation in Greenlandic cryoconite holes, Environ. Microbiol., 18, 4674-4686, https://doi.org/10.1111/1462-2920.13349, 2016.

Corcho Alvarado, J. A., Steinmann, P., Estier, S., Bochud, F., Haldimann, M., and Froidevaux, P.: Anthropogenic radionuclides in atmospheric air over Switzerland during the last few decades, Nat. Commun., 5, 3030, https://doi.org/10.1038/ncomms4030, 2014.

Dong, Z., Kang, S., Qin, D., Qin, X., Yan, F., Du, W., and Wei, T.: Temporal and diurnal analysis of trace elements in the Cryospheric water at remote Laohugou basin in northeast Tibetan Plateau, Chemosphere, 171, 386-398, https://doi.org/10.1016/j.chemosphere.2016.12.088, 2017.

Dowdall, M., Gerland, S., and Lind, B.: Gamma-emitting natural and anthropogenic radionuclides in the terrestrial environment of Kongsfjord, Svalbard, Sci. Total Environ., 305, 229-240, https://doi.org/0.1016/S0048-9697(02)00478-3, 2003.

Efurd, D. W., Steiner, R. E., Roensch, F. R., Glover, S. E., and Musgrave, J. A.: Determination of the $240 \mathrm{Pu} / 239 \mathrm{Pu}$ atom ratio in global fallout at two locations in the Northern Hemisphere, J. Radioanal. Nucl. Chem., 263, 387-391, https://doi.org/10.1007/s10967-005-0067-4, 2005.

Eyrikh, S., Eichler, A., Tobler, L., Malygina, N., Papina, T., and Schwikowski, M.: A 320 Year Ice-Core Record of Atmospheric $\mathrm{Hg}$ Pollution in the Altai, Central Asia, Environ. Sci. Technol., 51, 11597-11606, https://doi.org/10.1021/acs.est.7b03140, 2017.

Farmer, J. G., Eades, L. J., Mackenzie, A. B., Kirika, A., and BaileyWatts, T. E.: Stable lead isotope record of lead pollution in loch lomond sediments since 1630 A.D., Environ. Sci. Technol., 30, 3080-3083, https://doi.org/10.1021/es960162o, 1996.

Førland, E. J. I., Haugen, J. E., and Skaugen, T. E.: Temperature and precipitation development at Svalbard 1900-2100, Adv. Meteorol., 1-14, https://doi.org/10.1155/2011/893790, 2011.

Francis, A. J.: Microbial mobilization and immobilization of plutonium, J. Alloy. Compd., 444, 500-505, https://doi.org/10.1016/j.jallcom.2007.01.132, 2007.

Gadd, G. M.: Microbial influence on metal mobility and application for bioremediation, Geoderma, 122, 109-119, https://doi.org/10.1016/j.geoderma.2004.01.002 2004.

Gwynn, J. P., Dowdall, M., Davids, C., Selnæs, Ø. G., and Lind, B.: The radiological environment of Svalbard, Polar Res., 23, 167180, https://doi.org/10.1111/j.1751-8369.2004.tb00006.x, 2004.

Halbach, K., Mikkelsen, Ø., Berg, T., and Steinnes, E.: The presence of mercury and other trace metals in surface soils in the Norwegian Arctic, Chemosphere, 188, 567-574, https://doi.org/10.1016/j.chemosphere.2017.09.012, 2017.

Hardy, E. P., Krey, P. W., and Volchok, H. L.: Global inventory and distribution of fallout plutonium, Nature, 241, 444-445, https://doi.org/10.1038/241444a0, 1973.

Hao, L. Z., Wang, F., and Yang, H. Z.: Baseline values for heavy metals in soils on Ny-Alesund, Spitsbergen Island, Arctic: the extent of anthropogenic pollution, Adv. Mater. Res., 779-78, 12601265, https://doi.org/10.4028/www.scientific.net/AMR.779780.1260, 2013.

Headley, A. D.: Heavy metal concentrations in peat profiles from the high Arctic, Sci. Total Environ., 177, 105-111, https://doi.org/10.1016/0048-9697(95)04867-7, 1996.

Hirose, K. and Povinec, P. P.: Sources of plutonium in the atmosphere and stratosphere-troposphere mixing, Sci. Rep., 5, 15707, https://doi.org/10.1038/srep15707, 2015.

Hodson, A. Anesio, A. M., Tranter, M., Fountain, A., Osborn, M., Priscu, J., Laybourn-Parry, J., and Sattler, B.: Glacial ecosystems, Ecol. Monogr., 78, 41-67, https://doi.org/10.1890/07-0187.1, 2008.

Holm, E., Persson, B. R. R., Halstadius, L., Aarkrog, A., and Dahlgaard, H.: Radio-cesium and transuranium elements in the Greenland and Barenst Seas, Oceanol. Acta, 6, 457-462, 1983.

Hur, S. D., Cunde, X., Hong, S., Barbante, C., Gabrielli, P., Lee, K., Boutrone, C. F., and Ming, Y.: Seasonal patterns 
of heavy metal deposition to the snow on Lambert Glacier basin, East Antarctica Atmospheric Environment, 41, 85678578, https://doi.org/10.1016/j.atmosenv.2007.07.012, 2007.

Isaksen, K., Nordli, Førland, Ø. E. J., Łupikasza, E., Eastwood, S., and Niedźwiedź, T.: Recent warming on Spitsbergen and influence of atmospheric circulation and seaice cover, J. Geophys. Res.-Atmos., 121, 11913-11931, https://doi.org/10.1002/2016JD025606, 2016.

Kierepko, R., Mietelski, J. W., Ustrnul, Z., Anczkiewicz, R., Wershofen, H., Holgye, Z., Kapała, J., and Isajenko, K.: Plutonium isotopes in the atmosphere of Central Europe: isotopic composition and time evolution vs. circulation factors, Sci. Total Environ., 569, 937-947, https://doi.org/10.1016/j.scitotenv.2016.05.222, 2016.

Kozak, K., Kozioł, K., Luks, B., Chmiel, S., Ruman, M., Marć, M., Namieśnik, J., and Polkowska, Ż.: The role of atmospheric precipitation in introducing contaminants to the surface waters of the Fuglebekken catchment, Spitsbergen, Polar Res. 34, 24207, https://doi.org/10.3402/polar.v34.24207, 2015.

Lüdke, C., Skole, J., Taubner, K., and Krievs, M.: Trace metal analysis in arctic aerosols by an inductively coupled plasmatime of flight-mass spectrometer combined with an inductively heated vaporizer, Spectrochim. Acta B, 60, 1412-1422, https://doi.org/10.1016/j.sab.2005.08.014, 2005.

Łokas, E., Mietelski, J. W., Kleszcz, K., and Tomankiewicz, E.: A sequential procedure for determining ${ }^{238} \mathrm{Pu},{ }^{239+240} \mathrm{Pu},{ }^{241} \mathrm{Am}$, ${ }^{90} \mathrm{Sr}$, $\mathrm{U}$ and $\mathrm{Th}$ activities in soils and peats from Spitsbergen, Nukleonika, 55, 195-199, 2010.

Łokas, E., Mietelski, J. W., Ketterer, M. E., Kleszcz, K., Wachniew, P., Michalska, S., and Miecznik, M.: Sources and vertical distribution of Cs-137, Pu-238, Pu239+240 and Am-241 in peat profiles from southwest Spitsbergen. Appl. Geochem., 28, 100-108, https://doi.org/10.1016/j.apgeochem.2012.10.027, 2013.

Łokas, E., Bartmiński, P., Wachniew, P., Mietelski, J. W., Kawiak, T., and Środoń, J.: Sources and pathways of artificial radionuclides to soils at a High Arctic site, Environ. Sci. Pollut. Res., 21, 12479-12493, https://doi.org/10.1007/s11356-0143163-6, 2014.

Łokas, E., Zaborska, A., Kolicka, M., Różycki, M., and Zawierucha, K.: Accumulation of atmospheric radionuclides and heavy metals in cryoconite holes on an Arctic glacier, Chemosphere, 160, 162-172, https://doi.org/10.1016/j.chemosphere.2016.06.051, 2016.

Łokas, E., Mietelski, J.W., Anczkiewicz, R., and Kierepko, R.: Variations in $\mathrm{Pu}$ isotopic composition in soils from the Spitsbergen (Norway): Three potential pollution sources of the Arctic region, Chemosphere, 178, 231-238, https://doi.org/10.1016/j.chemosphere.2017.03.054, 2017a.

Łokas, E., Wachniew, P., Jodłowski, P., and Gąsiorek, M.: Airborne radionuclides in the proglacial environment as indicators of sources and transfers of soil material, J. Environ. Radioact., 178179, 193-202, https://doi.org/10.1016/j.jenvrad.2017.08.018, 2017 b.

Łokas, E., Zawierucha, K., Cwanek, A., Szufa, K., Gaca, P., Mietelski, J. W., and Tomankiewicz, E.: The sources of high airborne radioactivity in cryoconite holes from the Caucasus (Georgia), Sci. Rep., 8, 10802, https://doi.org/10.1038/s41598-018-290764, 2018.
Mietelski, J. W. and Wąs, B.: Plutonium from Chernobyl in Poland, App. Radiat. Isotopes 46, 11, 1203-1211, https://doi.org/10.1016/0969-8043(95)00162-7, 1995.

Mukaka, M. M.: A guide to appropriate use of correlation coefficient in medical research, Malawi Medical Journal, 24, 69-71, 2012.

Muramatsu, Y., Uchida, S., Tagami, K., Yoshida, Y., and Fujikawa, T.: Determination of plutonium concentration and its isotopic ratio in environmental materials by ICP-MS after separation using ion-exchange and extraction chromatography, J. Anal. At. Spectrom., 14, 859-865, https://doi.org/10.1039/A900071B, 1999.

Nørdli, Ø., Przybylak, R., Ogilvie, A. E. J., and Isaksen, K.: Longterm temperature trends and variability on Spitsbergen: the extended Svalbard Airport temperature series, 1898-2012, Pollut. Res., 33, 21-49, https://doi.org/10.3402/polar.v33.21349, 2014.

Nriagu, J. O.: A history of global metal pollution, Science, 272, 223-224, https://doi.org/10.1126/science.272.5259.223, 1996.

Ottesen, R. T., Bogen, J., and Finne, T. E.: Geochemical atlas of Norway. Part 2: Geochemical atlas of Spitsbergen, NGU, ISBN 978-82-7385-143-7, 2010.

Oughton, D. H., Skipperud, L., Fifield, L. K., Cresswell, R. G., Salbu, B., and Day, P.: Accelerator mass spectrometry measurement of $240 \mathrm{Pu} / 239 \mathrm{Pu}$ isotope ratios in Novaya Zemlya and Kara Sea sediments, Appl. Radiat. Isot., 61, 249-253, https://doi.org/10.1016/j.apradiso.2004.03.054, 2004.

Pacyna J. M. and Pacyna E. G.: An assessment of global and regional emissions of trace metals to the atmosphere from anthropogenic sources worldwide, Environ. Rev., 9, 269-298, https://doi.org/10.1139/a01-012, 2001.

Plichta, W.: Gleby Kaffiøyry, in: Kaffiøyra. Zarys środowiska geograficznego Kaffiøyry, edited by: Grześ, M. and Sobota, I., 3134 Oficyna Wydawnicza TURPRESS, Toruń, NW Spitsbergen, 2005.

Plichta, W. and Kuczyńska, I.: Metal contents in soils of Kaffioyra, Spitsbergen, Pol. Polar Res., 12, 183-193, 1991.

Radic, V., Bliss, A., Beedlow, A. C., Hock, R., Miles, E., and Graham Cogley, J. G.: Regional and global projections of twentyfirst century glacier mass changes in response to climate scenarios from global climate models, Clim. Dynam., 42, 37-58, https://doi.org/10.1007/s00382-013-1719-7, 2014.

Salminen-Paatero, S., Nygren, U., and Paatero, J.: ${ }^{240} \mathrm{Pu} /{ }^{239} \mathrm{Pu}$ mass ratio in environmental samples in Finland, J. Environ. Radioact., 113, 163-170, https://doi.org/10.1016/j.jenvrad.2012.06.005, 2012.

Samecka-Cymerman, A., Wojtuń, B., Kolon, K., and Kempers, A. J.: Sanionia uncinata (Hedw.) Loeske as bioindicator of metal pollution in polar regions, Pol. Biol., 34, 381-388, https://doi.org/10.1007/s00300-010-0893-x, 2011.

Segawa, T. Takeuchi, N., Rivera, A., Yamada, A., Yoshimura, Y., Barcaza, G., Shinbori, K., Motoyama, H., Kohshima, S., and Ushida, K.: Distribution of antibiotic resistance genes in glacier environments, Environ. Microbiol. Rep., 5, 127-134, https://doi.org/10.1111/1758-2229.12011, 2013.

Simon, S. L. and Bouville, A.: Radiation doses to local populations near nuclear weapons test sites worldwide, Health Phys., 82, 706-725, 2002.

Singh, S. M., Sharma, J., Gawas-Sakhalkar, P., Upadhyay, A. K., Naik, S., Pedneker, S. M., and Ravindra, R.: Atmospheric deposition studies of heavy metals in Arctic by comparative analysis 
of lichens and cryoconite, Environ. Monit. Assess., 185, 13671376, https://doi.org/10.1007/s10661-012-2638-5, 2013.

Smith, J. K., Ellis, K. M., Naes, K., Dahle, S., and Matishov, D.: Sedimentation and mixing rates of fallout radionuclides in Barents Sea sediments off Novaya Zemlya, Deep-Sea Res. Pt. II, 42, 1471-1493, https://doi.org/10.1016/0967-0645(95)00050-X, 1995.

Sobota, I.: The near-surface ice thermal structure of the Waldemarbreen, Svalbard, Pol. Polar Res., 30, 317-338, https://doi.org/10.4202/ppres.2009.17, 2009.

Sobota, I.: Snow accumulation, melt, mass loss, and the nearsurface ice temperature structure of Irenebreen, Svalbard, Polar Sci., 5, 321-336, https://doi.org/10.1016/j.polar.2011.06.003, 2011.

Sobota, I.: Selected problems of snow accumulation on glaciers during long-term studies in north-western Spitsbergen, Svalbard. Geografiska Ann. A, 99, 1-16, https://doi.org/10.1080/04353676.2017.1297679, 2017.

Sobota, I. and Lankauf, K. R.: Recession of Kaffiøyra Region glaciers, Oscar II Land. Svalbard, Bull. Geogr. 3, 27-45, 2010.

Sobota, I., Nowak, M., and Weckwerth, P.: Long-term changes of glaciers in northwestern Spitsbergen, Global Planet. Change, 144, 182-197, https://doi.org/10.1016/j.gloplacha.2016.07.006, 2016.

Sobota, I., Weckwerth, P., Grajewski, T., Dziembowski, M., Greń, K., and Nowak, M.: Short-term changes in thickness and temperature of the active layer in summer in the Kaffiøyra region, NW Spitsbergen, Svalbard, Catena, 160, 141-153, https://doi.org/10.1016/j.catena.2017.09.014, 2018.

StatSoft, Inc. Team: STATISTICA (data analysis software system), version 10. Tulsa, Oklahoma, StatSoft, Inc., 2011.

Takeuchi, N., Kohshima, S., Shiraiwa, T., and Kubota, K. Characteristics of cryoconite (surface dust on glaciers) and surface albedo of a Patagonian glacier, Tyndall Glacier, Southern Patagonia Icefield, Bull. Glaciol. Res., 18, 65-69, 2001a.

Takeuchi, N., Kohshima, S., and Seko, K.: Structure, formation, and darkening process of albedo-reducing material (cryoconite) on a Himalayan glacier: a granular algal mat growing on the glacier, Arct. Antarct. Alp. Res., 33, 115-122, https://doi.org/10.1080/15230430.2001.12003413, 2001b.

Taylor, R. N., Warneke, T., Milton, J. A., Croudace, I. W., Warwick, P. E., and Nesbitt, R. W.: Plutonium isotope ratio analysis at femtogram to nanogram levels by multicollector ICP-MS, J. Anal. Atom. Spectrom., 16, 279-284, https://doi.org/10.1039/B009078F, 2001.
UNSCEAR: Ionizing radiation: sources and biological effects. United Nations Scientific Committee on the effects of Atomic. Radiation, New York, 1982.

UNSCEAR: Sources and Effects of Ionizing Radiation, Report to the General Assembly, with scientific annexes, United Nations Scientific Committee on the Effects of Atomic Radiation, United Nations, New York, 1993, available at: http://www.unscear.org (last access: 1 February 2019), 1993.

Warneke, T., Croudace, I. W., Warwick, P. E., and Taylor, R. N.: A new ground-level fallout record of uranium and plutonium isotopes for northern temperate latitudes, Earth Planet. Sc. Lett., 203, 1047-1057, https://doi.org/10.1016/S0012821X(02)00930-5, 2002.

Wharton, R. A., McKay, C. P., Simmons, G. M., and Parker, B. C.: Cryoconite holes on glaciers, Bioscience, 35, 499-503, 1985.

Wojtuń, B., Samecka-Cymerman, A., Kolon, K., Kempers, A. J., and Skrzypek, G.: Metals Metals in some dominant vascular plants, mosses, lichens, algae, and the biological soil crust in various types of terrestrial tundra, SW Spitsbergen, Norway, Pol. Biol., 36, 1799-1809, https://doi.org/10.1007/s00300-013-13990,2013

Zaborska, A., Beszczyńska-Möller, A., and Włodarska-Kowalczuk M.: History of heavy metal accumulation in the Svalbard area: Distribution, origin and transport pathways, Environ. Pollut., 231, 437-450, https://doi.org/10.1016/j.envpol.2017.08.042, 2017.

Zawierucha, K. Buda, J., Pietryka, M., Richter, D., Łokas, E., Lehmann-Konera, S., Makowska, N., and Bogdziewicz, M.: Snapshot of micro-animals and associated biotic and abiotic environmental variables on the edge of the south-west Greenland ice sheet, Limnol., 19, 141-150, https://doi.org/10.1007/s10201017-0528-9, 2018.

Ziółek, M., Bartmiński, P., and Stach, A.: The Influence of Seabirds on the Concentration of Selected Heavy Metals in Organic Soil on the Bellsund Coast, Western Spitsbergen, Arct. Antarct. Alp. Res., 49, 507-520, https://doi.org/10.1657/AAAR0016024, 2017. 